\title{
ANALISIS RASIO KESEHATAN KEUANGAN DANA TABARRU' YANG MEMPENGARUHI PROFITABILITAS PADA ASURANSI SYARIAH DI INDONESIA (PERIODE 2012-2014)"1)
}

\author{
Estiningtyas Kusuma Safitri \\ Mahasiswa Program Studi S1 Ekonomi Islam-Fakultas Ekonomi dan Bisnis-Universitas Airlangga \\ Email: estiningtyas.kusuma-12@feb.unair.ac.id
}

Noven Suprayogi

Departemen Ekonomi Syariah-Fakultas Ekonomi dan Bisnis-Universitas Airlangga

Email: noven.suprayogi@feb.unair.ac.id

\begin{abstract}
:
The purpose of this research is to find out the effect of tabarru' fund financial health towards the profitability in insurance. The method that used in this research is quantitative method and also using secondary data which obtained from financial reports and other reports started from 2012 until the end of 2014. The choosing of sample was done using sampling purposive method and there are 28 Islamic insurances that comply with the specified sample criteria. Analysis technique used is multiple linier regression analysis of panel data. The result are risk based capital that have significant level less than 0,1 but liquidity ratio, balance investment liability ratio, investment income ratio, claim expenses ratio, and tabarru' fund change risk do not significantly influence the profitability of Islamic insurance companies because the significantly level more than 0,1 .
\end{abstract}

Keywords: Liquidity Ratio, Rate Balance Investment Liability, Investment Income ratio, Ratio of Claim Expenses and tabarru' fund change risk, Risk Based Capital and Profitability.

\section{Pendahuluan}

\section{Latar Belakang}

Peranan industri asuransi nasional adalah memberikan perlindungan /proteksi terhadap risiko yang dihadapi masyarakat sehingga menunjang stabilitas pembangunan dan sebagai salah satu lembaga penghimpun dana masyarakat dan penyedia dana untuk pembangungan ekonomi.

$$
\text { Layanan asuransi sebagai }
$$

pengambilahlian risiko membuat pelaku usaha dan lingkungan rumah tangga berencana untuk melindungi mereka terhadap risiko yang tidak pasti. Sebagai manusia kita tidak bisa memprediksi apa yang akan terjadi dikemudian hari seperti yang tertera dalam firman allah QS. AlLuqman 34 :

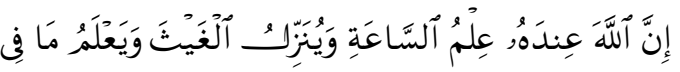

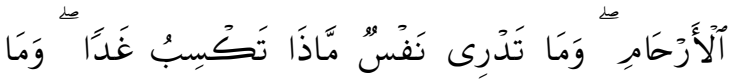

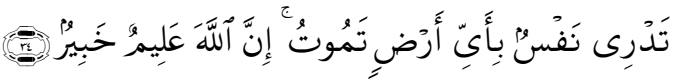

$$
\begin{aligned}
& \text { Innallāhā'indahū'ilmussā'ati wa }
\end{aligned}
$$

Asuransi syariah memiliki sistem yang berbeda dengan asuransi konvensional. Letak perbedaan asuransi syariah dengan konvensional adalah bagaimana risiko itu

1) Jurnal ini merupakan bagian dari skripsi yang ditulis oleh Estiningtyas Kusuma Safitri NIM: 041211431041 
Safitri, et al/Jurnal Ekonomi Syariah Teori dan Terapan Vol. 4 No. 1 Januari 2017: 73-88; ANALISIS RASIO KESEHATAN KEUANGAN DANA TABARRU' YANG MEMPENGARUHI PROFITABILITAS PADA ASURANSI SYARIAH DI INDONESIA (PERIODE 2012-2014)

dikelola dan ditanggung dan bagaimana asuransi syariah dikelola (labal, 2005:2).

Mekanisme pengelolaan dana pada asuransi syariah terdapat alokasi distribusi dana yaitu dana tabarru' dan dana saving, dimana bagian-bagian dana tersebut merupakan bagian yang tidak dapat dipisahkan dalam melakukan manajemen asuransi syariah (Ali, 2005:54).

Salah satu indikasi perusahaan asuransi yang terpercaya adalah perusahaan yang memiliki kesehatan keuangan yang baik (Pramestika,2014). Perusahaan Asuransi dikatakan sehat jika sudah memenuhi tingkat solvabilitas paling sedikit $120 \%$ itu berlaku untuk konvensional. Peraturan yang mengatur kesehatan keuangan asuransi syariah No: 11.PMK.010.2011 tentang ruang lingkup kesehatan perusahaan asuransi syariah meliputi dua hal yaitu kesehatan kevangan dana tabarru' dan dana perusahaan yang masing-masing memiliki batasan solvabilitas sendiri tingkat kesehatan dana tabarru' sebesar 30\% dan kesehatan dana perusahaan sebesar $70 \%$.

Perusahaan asuransi yang memiliki RBC lebih dari $30 \%$ akan lebih menarik perhatian masyarakat, karena masyarakat percaya bahwa mereka menempatkan dananya diperusahaan yang tepat. Penetapan nilai RBC diharapkan melindungi kepentingan nasabah dan dapat menjamin kecukupan modal pada perusahaan asuransi serta menghindarkan risiko yang dapat merugikan nasabah akibat deviasi dalam pengelolaan kekayaan dan kewajiban perusahaan asuransi yang bersangkutan.

Pengukuran kesehatan keuangan perusahan asuransi syariah berbeda dengan konvensional. Pengukuran kesehatan dana tabarru' ada dua jenis yang pertama kesehatan keuangan dari tingkat solvabilitas dan pengukuran kesehatan keuangan selain tingkat solvabilitas yang dicerminkan dari beberapa rasio seperti didalam peraturan Bapepam LK Nomor: PER-06/BL/2012 lima rasio yang terdiri dari rasio likuiditas, rasio perimbangan investasi dengan kewajiban, rasio pengembalian investasi neto, rasio beban klaim, dan rasio perubahan dana tabarru'. Pengukuran berdasarkan tingkat solvabilitas yaitu tercerminkan dari risk based capital (RBC) dana tabarru'.

Rasio-rasio tersebut menjadi karakteristik bagi perusahaan asuransi syariah karena sangat berbeda dengan lembaga keuangan lainnya. Perusahaan asuransi syariah tidak hanya sekedar mencapai tingkat kesehatan yang telah ditetapkan akan tetapi, juga mencari keuntungan dari hasil pengelolaan dana yang ada.

$\begin{array}{lll}\text { Setiap } & \text { perusahaan harus } \\ \text { mengalami perkembangan yang } \\ \text { meningkat }\end{array}$
Perkembangan bisa diketahui melalui tingkat profitabilitas yang dicapai selama periode tertentu. Profitabilitas juga digunakan untuk mengetahui efektifitas manajemen penggunaan dana perusahaan untuk menghasilkan laba. 
Safitri, et al/Jurnal Ekonomi Syariah Teori dan Terapan Vol. 4 No. 1 Januari 2017: 73-88; ANALISIS RASIO KESEHATAN KEUANGAN DANA TABARRU' YANG MEMPENGARUHI PROFITABILITAS PADA ASURANSI SYARIAH DI INDONESIA (PERIODE 2012-2014)

Tuntutan bagi perusahaan asuransi syariah untuk mencapai laba secara optimal akan terbatas dengan ketentuan dalam memenuhi tingkat solvabilitaas dana tabarru' jaminan baik berupa modal atau aktiva yang harus dimiliki perusahaan untuk meanggulagi risiko terhadap kewajiban semakin tinggi, sehingga pengelolaan investasi akan kurang efisien dan cenderung memilih investasi beresiko rendah hal ini dapat mempengaruhi profitabilitasnya (Fitriani, 2015).

Perusahaan asuransi memperoleh dana dari berbagai sumber yang kemudian diolah perusahaan untuk mendapatkan hasil dari pengelolan dana tersebut. Dananya berasal dari total investasi atau aset yang dimilikinya dan dari modal atau ekuitas yang tertanam didalam perusahaan.

Penelitian ini menggunakan ROE (Return On Equity), dimana rasio tersebut menunjukan kemampuan perusahaan dalam menghasilkan laba bersih untuk pengembalian ekuitas pemegang saham, semakin besar ROE maka kinerja perusahaan semakin baik.

Semakin besar tingkat profitabilitas yang dicerminkan oleh ROE menunjukan bahwa kinerja manajemen meningkat dalam mengelola sumber dana pembiayaan operasional secara efektif untuk menghasilkan laba bersih. Kemampuan dalam mengelola manajemen dan kondisi keuangan perusahaan juga terus diperbaiki guna memberikan citra yang positif bagi peserta dan masyarakat umum.
Berdasarkan uraian latar belakang diatas peneliti tertarik untuk membahas pengaruhnya rasio kesehatan keuangan dana tabarru' terhadap profitabilitas pada perusahaan asuransi syariah di Indonesia periode 2011-2014 untuk menjadi topik penelitian ini. Peneliti merumuskan masalah penelitian sebagian berikut:

1. Apakah rasio likuiditas, rasio perimbangan investasi dengan kewajiban, rasio pendapatan investasi neto, rasio beban klaim, rasio perubahan dana tabarru', rasio risk based capital secara simultan berpengaruh signifikan terhadap profitabilitas perusahaan asuransi syariah di Indonesia periode 2012-2014?

2. Apakah rasio likuiditas secara parsial berpengaruh signifikan terhadap profitabilitas perusahaan asuransi syariah di Indonesia periode 2012-2014?

3. Apakah rasio perimbangan investasi dengan kewajiban secara parsial berpengaruh signifikan terhadap profitabilitas perusahaan asuransi syariah di Indonesia periode 2012-2014?

4. Apakah rasio pendapatan investasi neto secara parsial berpengaruh signifikan terhadap profitabilitas perusahaan asuransi syariah di Indonesia periode 2012-2014?

5. Apakah rasio beban klaim secara parsial berpengaruh signifikan terhadap profitabilitas perusahaan asuransi syariah di Indonesia periode 2012-2014? 
Safitri, et al/Jurnal Ekonomi Syariah Teori dan Terapan Vol. 4 No. 1 Januari 2017: 73-88; ANALISIS RASIO KESEHATAN KEUANGAN DANA TABARRU' YANG MEMPENGARUHI PROFITABILITAS PADA ASURANSI SYARIAH DI INDONESIA (PERIODE 2012-2014)

6. Apakah rasio perubahan dana tabarru' secara parsial berpengaruh signifikan terhadap profitabilitas perusahaan asuransi syariah di Indonesia periode 2012-2014?

7. Apakah risk based capital secara parsial berpengaruh signifikan terhadap profitabilitas perusahaan asuransi syariah di Indonesia periode 2012-2014?

Adapun tujuan penelitian ini adalah:

1. Untuk mengetahui pengaruh rasio likuiditas, rasio perimbangan investasi dengan kewajiban, rasio pendapatan investasi neto, rasio beban klaim, rasio perubahan dana tabarru', rasio risk based capital secara simultan terhadap profitabilitas perusahaan asuransi syariah di Indonesia periode 2012-2015.

2. Untuk mengetahui pengaruh rasio likuiditas, rasio perimbangan investasi dengan kewajiban, rasio pendapatan investasi neto, rasio beban klaim, rasio perubahan dana tabarru' dan rasio risk based capital terhadap profitabilitas perusahaan asuransi syariah di Indonesia periode 2012-2015.

\section{LANDASAN PUSTAKA}

Menurut Dewan Syariah Nasional, Majelis Ulama Indonesia (DSN-MUI) dalam fatwa No.21/DSN-MUI/X/2001 tentang pedoman asuransi syariah mendefinisikan: "Asuransi syariah (ta'amin, takaful,
tadhamun) adalah usaha saling
melindungi dan tolong menolong
diantara sejumlah orang atau pihak
melalui dana investasi dalam bentuk
aset dan atau tabarru' yang
memberikan pola pengembalian

untuk menghadapi resiko tertentu melalui akad atau perikatan yang sesuai dengan syariah."

Peraturan Menteri Keuangan Republik Indonesia Nomor 11/PMK.010-2011 menyatakan bahwa setiap perusahaan asuransi syariah wajib menjaga solvabilitasnya baik dana tabarru' maupun dana perusahaan. Tingkat solvabilitas merupakan selisish antara jumlah kekayaan yang diperkenankan dan kewajiban. Jumlah tingkat solvabilitas tersebut sekurang-kraungnya harus sebesar dana yang cukup untuk menutup risiko kerugian yang mungkin timbil sebagai akibat dari terjadinya deviasi dalam pengelolaan kekayaan dan kewajiban. Perusahaan asuransi dan perusahaan reasuransi setiap saaat wajib memenuhi tingkat solvabilitas paling sedikit 30\% untuk dana tabarru' dan $70 \%$ untuk dana perusahaan.

Indikator pengukuran kinerja dan kesehatan keuangan merupakan salah satu faktor penting dalam perusahaan. Pengukuran kinerja dan kesehatan pada perusahaan umumnya menilai laporan kevangan yang dapat dijadikan sebagai tolak ukur apakah perusahaan sudah baik dari segi keuangan maupun nonkeuangan. Untuk melihat kesehatan kevangan yang sesuai dengan peraturan BAPEPAM LK yang terbagi menjadi dua yaitu kesehatan keuangan berdasarkan tingkat solvabilitas dan selain tingkat solvabilitas.

$$
\text { Rasio kesehatan keuangan }
$$
berdasarkan tingkat solvabilitas diukur melalui risk based capital. Risk Based 
Safitri, et al/Jurnal Ekonomi Syariah Teori dan Terapan Vol. 4 No. 1 Januari 2017: 73-88; ANALISIS RASIO KESEHATAN KEUANGAN DANA TABARRU' YANG MEMPENGARUHI PROFITABILITAS PADA ASURANSI SYARIAH DI INDONESIA (PERIODE 2012-2014)

Capital menunjukan kemampuan perusahaan asuransi dalam memenuhi kewajiban asuransi dan reasuransi dengan mengetahui besarnya kebutuhan modal perusahaan dalam mengelola kekayaan dan kewajiban. Komponen-komponen Batas Tingkat Solfabilitas Minimum (BTSM) antara lain: Kegagalan pengelolaan kekayaan, Ketidakseimbangan antara nilai kekayaan dan kewajiban dalam setiap jenis mata vang, Perbedaan antara beban klaim yang terjadi dan beban klaim yang diperkirakan, Ketidakseimbangan pihak reasuradur untuk memenuhi kewajiban membayar klaim.

Asuransi syariah memiliki dua komponen tambahan ketidakseimbangan antara proyeksi arus kekayaan dan kewajiban dan kontribusi dengan hasil investasi yang diperoleh. Komponen perhitungan rasio Risk Based Capital diatas dapat juga dihitung dengan prosedur dalam ketentuan Ketua Badan Pengawas Pasar Modal dan Lembaga Keuangan Nomor: PER-06/BL/2011.

Rasio kesehatan keuangan berdasarkan selain tingkat solvabilitas BAPEPAM PER-06/BL/2011 menjelaskan rasio kesehatan selain tingkat solvabilitas yang terdapat didalam susunan laporan dana tabarru' asuransi dengan prinsip syariah penjelasannya sebagai berikut :

1. Rasio Likuiditas

Rasio ini mengukur kemampuan
perusahaan dalam memenuhi
kewajiban dan secara kasar
memberikan kondisi keuangan

perusahaan asuransi apakah dalam kondisi solven atau tidak (Satria, 1994:72).

2. Rasio Perimbangan Investasi dengan kewajiban

Rasio ini menggambarkan tentang investasi yang digunakan untuk mengcover kewajiban yang dimiliki oleh perusahaan. Aktiva lancar yang terdiri dari kas, bank dan investasi yang dilakukan perusahaan untuk mengelola dana dan memberikan informasi vang yang likuid, sementara penyisihan teknis menggambarkan tingkat kecukupan cadangan yang diperlukan dalam menghadapi kewajiban yang timbul dari penutupan resiko, selain itu retensi sendiri mengukur besar premi yang ditahan sendiri dibanding premi yang diterima secara langung

3. Rasio Pendapatan Investasi neto

Rasio pendapatan investasi atau Investment Yield Ratio adalah pengembalian investasi memberikan indikasi secara umum mengenai kualitas setiap jenis investasi serta mengukur hasil return dari investasi (Satria, 1994:71)

\section{Rasio Beban Klaim}

Rasio ini mencerminkan pengalaman klaim (loss ratio) yang terjadi serta kualitas usaha penutupannya. Rasio ini mencerminkan klaim yang terjadi selama periode berjalan serta menunjukan kualitas usaha dalam penutupan klaim yang terjadi. 
Safitri, et al/Jurnal Ekonomi Syariah Teori dan Terapan Vol. 4 No. 1 Januari 2017: 73-88; ANALISIS RASIO KESEHATAN KEUANGAN DANA TABARRU' YANG MEMPENGARUHI PROFITABILITAS PADA ASURANSI SYARIAH DI INDONESIA (PERIODE 2012-2014)

5. Rasio Perubahan Dana Tabarru' Rasio pertumbuhan ini menggambarkan kenaikan atau penurunan yang tajam pada volume premi neto memberikan indikasi kurangnya tingkat kestabilan kegiatan operasi perusahaan.

Profitabilitas menggambarkan kemampuan perusahaan mendapatkan laba melalui semua kemampuan dan sumber yang ada seperti kegiatan penjualan, kas, modal jumlah karyawan, jumlah cabang dan sebagainya (Harahap, 2001:304). Rasio profitabilitas yang digunakan dalam penelitian ini adalah ROE (Return on Equity. Rasio ini menunjukan kemampuan perusahaan dengan modal sendiri untuk menghasilkan laba bersih, Besarnya tingkat ROE yang dihasilkan oleh suatu perusahaan menunjukan seberapa besar laba yang dihasilkan tiap rupiah modal sendiri yang ditanam dalam perusahaan.

Berdasarkan latar belakang, rumusan masalah, tujuan penelitian, landasan teori yang telah dikemukakan maka hipotesis dalam penelitian ini adalah:

Hipotesis secara parsial:

$\begin{array}{rlr}\mathrm{H}_{1} \text { : } & \text { Rasio likuiditas berpengaruh } \\ & \text { signifikan positif } & \text { terhadap } \\ & \text { profitabilitas pada perusahaan } \\ & \text { asuransi syariah di Indonesia. }\end{array}$

$\mathrm{H}_{2}$ : Rasio perimbangan investasi dengan kewajiban berpengaruh signifikan positif terhadap profitabilitas pada perusahaan asuransi syariah di Indonesia.

$\mathrm{H}_{3}$ : Rasio pendapatan investasi neto berpengaruh signifikan positif terhadap profitabilitas pada perusahaan asuransi syariah di Indonesia.

$\mathrm{H}_{4}$ : Rasio beban klaim berpengaruh signifikan positif terhadap profitabilitas pada perusahaan asuransi syariah di Indonesia.

$\mathrm{H}_{5}$ : Rasio perubahan dana tabarru' berpengaruh signifikan positif terhadap profitabilitas pada perusahaan asuransi syariah di Indonesia.

$\mathrm{H}_{6}$ : Rasio risk based capital berpengaruh signifikan positif terhadap profitabilitas pada perusahaan asuransi syariah di Indonesia.

$\mathrm{H}_{7}$ : rasio likuiditas, rasio perimbangan investasi dengan kewajiban, rasio pendapatan investasi neto, rasio beban klaim, rasio perubahan dana tabarru' dan rasio risk based capital secara simultan berpengaruh signifikan positif terhadap profitabilitas perusahaan asuransi syariah di Indonesia.

\section{METODE PENELITIAN}

\section{Pendekatan Penelitian}

Pendekatan yang digunakan dalam penelitian ini adalah pendekatan kuantitatif. Alat analisis kuantitatif yang digunakan dalam penelitian ini adalah regresi berganda data panel. 
Safitri, et al/Jurnal Ekonomi Syariah Teori dan Terapan Vol. 4 No. 1 Januari 2017: 73-88; ANALISIS RASIO KESEHATAN KEUANGAN DANA TABARRU' YANG MEMPENGARUHI PROFITABILITAS PADA ASURANSI SYARIAH DI INDONESIA (PERIODE 2012-2014)

\section{Variabel Dependen}

1. Rasio profitabilitas

Variabel pengukuran kinerja keuangan peruasahaan dalam menghasilkan laba bersih setelah pajak terhadap modal.

Rumus:

Laba bersih setelah pajak Modal Sendiri

Dalam penelitian ini, data yang digunakan adalah dalam satuan persentase.

\section{Variabel Independen}

1. Rasio likuiditas

kekayaan lancar yang dimiliki oleh perusahaan asuransi syariah dibagi dengan kewajiban lancar yang menjadi tanggungan perusahaan asuransi syariah.

Rumus likuiditas:

kekayaan lancar kewajiban lancar

Dalam penelitian ini, data yang digunakan merupakan data dalam satuan persentase.

2. Rasio Perimbangan Investasi dengan Kewajiban

Rasio perimbangan investasi dengan kewajiban adalah gabungan beberapa aktiva seperti investasi, kas dan bank yang dimiliki oleh perusahaan asuransi syariah dibagi dengan hasil penjumlahan dari penyisihan teknis dan utang klaim retensi sendiri.

Rumus:

Perimbangan investasi dengan kewajiban

$=\frac{\text { investasi,kas dan bank }}{\text { penyisihan teknis+utang klaim }}$

3. Rasio Pendapatan Investasi pendapatan investasi neto adalah total pendapatan yang diperoleh perusahaan asuransi dibagi dengan rata-rata investasi yang dilakukan Rumus pendapatan investasi neto:

$=\frac{\text { Pendapatan Investasi Neto }}{\text { Rata-rata Investasi }}$

Dalam penelitian ini, data yang digunakan merupakan data dalam satuan persentase.

4. Rasio Beban Klaim

beban klaim neto yang diperoleh pihak asuransi syariah dibanding dengan kontribusi neto yang diterima oleh pihak asuransi syariah.

Rumus beban klaim :

beban klaim neto

kontribusi neto

5. Rasio Perubahan Dana tabarru'

rasio yang menunjukan perubahan dana tabarru' dari periode berjalan kemudian dikurangi dengan periode yang lalu kemudian hasil yang diperoleh dibagi dengan dana tabarru' periode yang lalu.

Rumusnya adalah :

(Prubhan dana tabarru'n)(Prubahan dana tabarru' $\mathrm{n}-1$ ) (Prubahan dana tabarru' $\mathrm{n}-1$ )

6. Rasio Risk Based Capital rasio dari jumlah tingkat solvabilitas yang didalamnya terdapat nilai kekayaan yang diperkenankan dikurangi dengan jumlah kewajiban, dibagi dengan batas tingkat solvabilitas minimum.

Rumusnya adalah

Tingkat Solvabilitas Batas Tingkat Solvabilitas Minimum 
Safitri, et al/Jurnal Ekonomi Syariah Teori dan Terapan Vol. 4 No. 1 Januari 2017: 73-88; ANALISIS RASIO KESEHATAN KEUANGAN DANA TABARRU' YANG MEMPENGARUHI PROFITABILITAS PADA ASURANSI SYARIAH DI INDONESIA (PERIODE 2012-2014)

\section{Jenis dan Sumber Data}

Data yang digunakan dalam penelitian ini merupakan data sekunder. Data tersebut diperoleh dari laporan kevangan tahunan perusahaan asuransi syariah melalui website resmi. Dalam penelitian ini, gabungan data dari variabel profitabilitas, rasio likuiditas, rasio perimbangan investasi dengan kewajiban, rasio pendapatan investasi neto, rasio beban klaim, rasio perubahan dana tabarru', rasio risk based capital dan ROE dari beberapa perusahaan asuransi syariah selama 3 tahun periode sehingga menciptakan data panel.

\section{Populasi dan Sampel}

Populasi dalam penelitian ini adalah semua perusahaan asuransi dan reasuransi di Indonesia. Untuk pemilihan sampel, metode yang digunakan adalah metode sampling purposive dengan kriteria termasuk perusahaan asuransi di Indonesia yang mengeluarkan laporan keuangannya dari tahun 2011, tidak termasuk perusahaan reasuransi, mulai beroperasi sebelum tahun 2010.

Berdasarkan kriteria pemilihan sampel tersebut terdapat 28 perusahaan asuransi syariah bank yang digunakan sebagai sampel. Jumlah data yang digunakan sebagai sampel dalam penelitian ini adalah 84 data.

Tabel 1.

Daftar Sampel Perusahaan Asuransi

\begin{tabular}{|c|l|}
\hline No & \multicolumn{1}{|c|}{ Perusahaan } \\
\hline 1 & PT. Asuransi Takaful Keluarga \\
\hline 2 & PT. Asuransi Jiwa Syariah Al Amin \\
\hline 3 & $\begin{array}{l}\text { PT Asuransi Jiwa Bersama Bumiputera } \\
1912\end{array}$ \\
\hline
\end{tabular}

\begin{tabular}{|l|l|}
\hline 4 & PT Asuransi Avrist Assurance \\
\hline 5 & PT Asuransi Allianz Life Indonesia \\
\hline 6 & PT Asuransi Jiwa Bringin Jiwa Sejahtera \\
\hline 7 & PT Asuransi Jiwa Central Asia Raya \\
\hline 8 & PT Jiwa Mega Life \\
\hline 9 & PT Jiwa Sinar Mas MSIG \\
\hline 10 & PT BNI Life Insurance \\
\hline 11 & PT Tokio Marine Life \\
\hline 12 & PT Prudential Life Assurance \\
\hline 13 & AXA Mandiri \\
\hline 14 & PT Asuransi Jiwa Manulife Indonesia \\
\hline 15 & Panin Daichi Life \\
\hline 16 & AIA Financial \\
\hline 17 & Sun Life Financial Indonesia \\
\hline 18 & PT Asuransi Takaful Umum \\
\hline 19 & PT Asuransi Adira Dinamika \\
\hline 20 & PT Asuransi Bintang Tbk. \\
\hline 21 & PT Asuransi Umum Bumiputera Muda \\
\hline 22 & PT Asuransi Central Asia \\
\hline 23 & PT Asuransi Jasa Indonesia (Persero) \\
\hline 24 & PT Asuransi Parolamas \\
\hline 25 & PT Asuransi Ramayana Tbk. \\
\hline 26 & PT Asuransi Sinarmas \\
\hline 27 & Asuransi Umum Mega Syariah \\
\hline 28 & AIG Syariah Insurance Indonesia \\
\hline & Sumber : data diolah peneliti \\
Teknik Analisis \\
Regresi Data Panel \\
\hline
\end{tabular}

Data panel merupakan gabungan antara data time series dengan data cross section. Data time series yaitu data yang berupa nilai dari satu atau lebih variabel selama satu periode. Data cross section yaitu nilai dari satu atai lebih, variabel yang diambil dari beberapa unit sampel dalam periode waktu yang sama (Gujarati, 2013: 235). Menurut Greene (1991:481) dalam mengestimasi data panel terdapat tiga pendekatan yang biasa dilakukan, yaitu model PLS, model fixed effect (FEM), model random effect (REM).

1. PLS 
Safitri, et al/Jurnal Ekonomi Syariah Teori dan Terapan Vol. 4 No. 1 Januari 2017: 73-88; ANALISIS RASIO KESEHATAN KEUANGAN DANA TABARRU' YANG MEMPENGARUHI PROFITABILITAS PADA ASURANSI SYARIAH DI INDONESIA (PERIODE 2012-2014)

Teknik yang paling sederhana untuk mengestimasi data panel adalah hanya dengan mengkombinasikan data time series dan cross section.

\section{Fixed Effect}

Model ini didasarkan adanya perbedaan intersep antara subjek penelitian namun intersepnya sama antar waktu. Selain itu model ini juga mengasumsikan bahwa koefisien regresi (slope) adalah tetap untuk antar subjek penelitian dan antar waktu. Model ini menambahkan variabel dummy untuk mengizinkan adanya perubahan intersep antar subjek.

\section{Random Effect}

Model ini mengestimasi data panel dimana variabel gangguan mungkin saling berhubungan antar waktu dan antar inidividu dan diasumsikan setiap subjek penelitan memiliki perbedaan intersep.

Untuk menentukan teknik yang paling tepat dalam mengestimasi regresi data panel, terdapat beberapa pengujian yang dilakukan. Pertama adalah uji statistik $F$ (Uji Chow) yang digunakan untuk memilih antara metode PLS atau FEM. Pengambilan keputusan uji chow didasarkan dari nilai probabilitas, dimana jika $p$-value $<0,05$ maka penggunaan metode FEM lebih baik daripada metode PLS. Yang kedua adalah uji Hausman yang digunakan untuk memilih antara metode FEM atau REM. Pengambilan keputusan juga didasarkan dari nilai probabilitas, dimana jika $p$-valve $<0,05$ maka metode FEM lebih baik dari REM.
Metode panel memiliki beberapa keunggulan yang mana keunggulan tersebut dapat meminimalkan bias yang mungkin ditimbulkan oleh agregasi data individu. Keunggulan-keunggulan tersebut memiliki implikasi pada tidak harus dilakukan pengujian asumsi klasik dalam model data panel (Verbeek (2000); Gujarati (2003); Wibisono (2005); Aulia (2004:27) dalam Aijja (2011:52)).

\section{Uji Hipotesis}

Uji $F$

Uji $\mathrm{F}$ bertujuan untuk mengetahui pengaruh semua variabel independen dalam satu model regresi terhadap variabel dependen. Pengujian dilakukan dengan menggunakan significance level $0,05(a=5 \%)$. Apabila signifikansi $<0,05$, maka $\mathrm{H}_{0}$ ditolak atau secara simultan semua variabel independen berpengaruh secara signifikan terhadap variabel dependen.

Uji $\boldsymbol{t}$

Uji † dilakukan untuk membuktikan apakah variabel independen secara individu mempengaruhi variabel dependen. Pengujian dilakukan dengan menggunakan significance level 0,1 $(a=10 \%)$. Apabila signifikansi $<0,05$, maka Ho ditolak atau secara parsial variabel independen berpengaruh secara signfikan terhadap variabel dependen. Sebaliknya, bila signifikansi > 0,05 maka $\mathrm{H}_{0}$ diterima atau secara parsial variabel independen berpengaruh tidak signifikan terhadap variabel dependen.

\section{Koefisien Determinasi}


Safitri, et al/Jurnal Ekonomi Syariah Teori dan Terapan Vol. 4 No. 1 Januari 2017: 73-88; ANALISIS RASIO KESEHATAN KEUANGAN DANA TABARRU' YANG MEMPENGARUHI PROFITABILITAS PADA ASURANSI SYARIAH DI INDONESIA (PERIODE 2012-2014)

Koefisien determinasi $\left(R^{2}\right)$ digunakan untuk mengukur persentase total variasi variabel dependen yang dapat dijelaskan oleh variabel independen dalam garis regresi dan mengetahui seberapa kuat pengaruh variabel bebas dalam menerangkan variabel terikat.

\section{HASIL DAN PEMBAHASAN}

Berdasarkan tabel 2 dapat diketahui bahwa dengan melakukan uji chow, metode FEM lebih baik daripada metode PLS karena nilai prob. Crosssection chi-square yang kurang dari 0,05. Selanjutnya dilakukan Uji Hausman untuk mengetahui apakah model FEM lebih baik dari model REM. Dari tabel 3 diketahui bahwa nilai prob. Cross-section random juga kurang dari 0,05 sehingga metode FEM lebih baik daripada metode REM.

Tabel 2.

Hasil Perhitungan Uji Chow

\begin{tabular}{|c|c|c|c|}
\hline Effects Test & Statistic & d.f. & Prob. \\
\hline $\begin{array}{c}\text { Cross- } \\
\text { section F }\end{array}$ & 9.783864 & $(27,50)$ & 0.0000 \\
\hline $\begin{array}{c}\text { Cross- } \\
\text { section } \\
\text { Chi-square }\end{array}$ & 154.38327 & 27 & 0.0025 \\
\hline
\end{tabular}

Sumber: Data Diolah, lihat lampiran 5.

Tabel 3.

Hasil Perhitungan Uji Hausman

\begin{tabular}{|c|c|c|c|}
\hline $\begin{array}{c}\text { Test } \\
\text { Summary }\end{array}$ & Statistic & d.f. & Prob. \\
\hline $\begin{array}{c}\text { Cross- } \\
\text { section } \\
\text { random }\end{array}$ & 16.852545 & 6 & 0.0098 \\
\hline
\end{tabular}

Sumber: Data Diolah, lihat lampiran 7.

Berdasarkan tabel 4, hasil estimasi model FEM yang terbentuk adalah:

$$
\begin{aligned}
& Y=a+\beta_{1} X_{1 i t}+\beta_{2} X_{2 i t}+\beta_{3} X_{3 i t}+\beta_{4} D_{1 i}+ \\
& \beta_{5} D_{2 i}+\beta_{6} D_{3 i}+\beta_{7} D_{4 i}+\beta_{8} D_{5 i}+\beta_{9} D_{6 i}+ \\
& \varepsilon i+. \\
& 0.019773 X_{3}-0.000246 X_{4}+0.013382 \\
& X_{5}+0.008401 X_{6}
\end{aligned}
$$

Tabel 4

Output EViews 7 Estimasi Data Panel dengan metode FEM

\begin{tabular}{|c|c|c|c|c|}
\hline Variabel & Coefficient & Std. Error & t-Statistic & Prob. \\
\hline C & 20.26543 & 4.418214 & 4.586764 & 0 \\
\hline LIKUIDITAS & -0.002647 & 0.0126 & -0.21767 & 0.8286 \\
\hline PIK & -0.008563 & 0.007185 & -1.19175 & 0.239 \\
\hline PIN & -0.019773 & 0.180161 & -0.10975 & 0.913 \\
\hline BK & -0.000246 & 0.010613 & -0.02321 & 0.9816 \\
\hline PDT & 0.013382 & 0.013231 & 1.011416 & 0.3167 \\
\hline RBC & 0.008401 & 0.004481 & 1.874829 & 0.0667 \\
\hline \multicolumn{5}{|c|}{ Effects Specification } \\
\hline Cross-section fixed (dummy variabels) \\
\hline R-squared & 0.875991 \\
\hline Adjusted R-squared & 0.794146 \\
\hline F-statistic & 10.70296 \\
\hline Prob(F-statistic) & 0.00000 \\
\hline Durbin-Watson stat & 2.180223 \\
\hline
\end{tabular}

Sumber: Data Diolah, lihat lampiran 4

Uji $F$

Berdasarkan tabel 4 dapat

diketahui bahwa signifikansi yang dihasilkan sebesar 0,000 . Nilai signifikansi tersebut lebih kecil dari 0,05 . Sehingga $\mathrm{H}_{7}$ diterima. Artinya variabel rasio likuiditas, 
Safitri, et al/Jurnal Ekonomi Syariah Teori dan Terapan Vol. 4 No. 1 Januari 2017: 73-88; ANALISIS RASIO KESEHATAN KEUANGAN DANA TABARRU' YANG MEMPENGARUHI PROFITABILITAS PADA ASURANSI SYARIAH DI INDONESIA (PERIODE 2012-2014)

rasio perimbangan investasi dengan kewajiban, rasio pendapatan investasi neto, rasio beban klaim, rasio perubahan dana tabarru' dan rasio risk based capital secara simultan berpengaruh signifikan positif terhadap profitabilitas perusahaan asuransi syariah di Indonesia pada periode 2012-2015.

Tabel 5.

Output EViews 7 Hasil Uji F

\begin{tabular}{|c|c|}
\hline F-statistic & 10.70296 \\
\hline Prob(F-statistic) & 0.000000 \\
\hline
\end{tabular}

Sumber: Data Diolah, lihat lampiran 4.

Uji $t$

Berdasarkan pengujian pada tabel 5 maka dapat disimpulkan sebagai berikut:

a. Pengaruh rasio likuiditas terhadap profitabilitas

Nilai signifikansi dari rasio likuiditas adalah 0.8286 . Nilai tersebut lebih kecil dari 0,1 sehingga $H_{1}$ ditolak atau dengan kata lain rasio likuiditas secara parsial berpengaruh tidak signifikan terhadap profitabilitas.

b. Pengaruh rasio perimbangan investasi dengan kewajiban terhadap profitabilitas

Nilai signifikansi dari rasio perimbangan investasi dengan kewajiban adalah 0.239. Nilai tersebut lebih besar dari 0,1 sehingga $\mathrm{H}_{2}$ ditolak atau dengan kata lain rasio perimbangan investasi secara parsial berpengaruh tidak signifikan terhadap profitabilitas.

c. Pengaruh rasio pendapatan investasi neto terhadap profitabilitas

Nilai signifikansi dari rasio pendapatan investasi neto adalah 0.913. Nilai tersebut lebih besar dari 0,1 sehingga
$\mathrm{H}_{3}$ ditolak atau dengan kata lain rasio pendapatan investasi neto secara parsial berpengaruh tidak signifikan terhadap profitabilitas.

d. Pengaruh rasio beban klaim terhadap profitabilitas

Nilai signifikansi dari rasio beban klaim adalah 0.9816 . Nilai tersebut lebih besar dari 0,1 sehingga $\mathrm{H}_{4}$ ditolak atau dengan kata lain rasio beban klaim secara parsial berpengaruh tidak signifikan terhadap profitabilitas.

e. Pengaruh rasio perubahan dana tabarru' terhadap profitabilitas

Nilai signifikansi dari rasio perubahan dana tabarru' adalah 0.3167. Nilai tersebut lebih besar dari 0,1 sehingga $\mathrm{H}_{5}$ ditolak atau dengan kata lain rasio perubahan dana tabarru' secara parsial berpengaruh tidak signifikan terhadap profitabilitas.

f. Pengaruh rasio risk based capital terhadap profitabilitas

Nilai signifikansi dari rasio risk based capital adalah 0.0667 . Nilai tersebut lebih kecil dari 0,1 sehingga $\mathrm{H}_{6}$ diterima atau dengan kata lain rasio risk based capital secara parsial berpengaruh signifikan terhadap profitabilitas.

Tabel 6.

Output Eviews 7 Hasil Uji $t$

\begin{tabular}{|l|l|l|}
\hline \multicolumn{1}{|c|}{ Variable } & \multicolumn{1}{c|}{ t-Statistic } & \multicolumn{1}{c|}{ Prob. } \\
\hline Likuiditas & -0.21767 & 0.8286 \\
\hline PIK & -1.19175 & 0.239 \\
\hline PIN & -0.10975 & 0.913 \\
\hline BK & -0.02321 & 0.9816 \\
\hline PDT & 1.011416 & 0.3167 \\
\hline RBC & 1.874829 & 0.0667 \\
\hline
\end{tabular}

Sumber: Data Diolah, lihat lampiran 4 Koefisien Determinasi 
Safitri, et al/Jurnal Ekonomi Syariah Teori dan Terapan Vol. 4 No. 1 Januari 2017: 73-88; ANALISIS RASIO KESEHATAN KEUANGAN DANA TABARRU' YANG MEMPENGARUHI PROFITABILITAS PADA ASURANSI SYARIAH DI INDONESIA (PERIODE 2012-2014)

Berdasarkan tabel 7 diperoleh nilai koefisien determinasi $\left(R^{2}\right)$ sebesar 0.875991 atau $87.5991 \%$. Angka tersebut menunjukkan bahwa variabel profitabilitas yang dicerminkan oleh ROE dapat dijelaskan oleh variabel rasio likuiditas, rasio perimbangan investasi dengan kewajiban, rasio pendapatan investasi neto, rasio beban klaim, rasio perubahan dana tabarru' dan rasio risk based capital sebesar $87.5991 \%$. Sedangkan sisanya yaitu $12.4009 \%$ dipengaruhi oleh variabel lain yang tidak termasuk dalam penelitian ini.

Tabel 7.

Output Eviews 8 Hasil Koefisien Determinasi

\begin{tabular}{|c|c|}
\hline R-Squared & Adjusted R-Squared \\
\hline 0.875991 & 0.794145 \\
\hline
\end{tabular}

Sumber: Data Diolah, lihat lampiran 9.

Pembahasan

Pengaruh Rasio Kesehatan Kevangan

Dana Tabarru' selain Tingkat Solvabilitas Terhadap Profitabilitas

Hasil dari regresi data panel yang menggunakan metode Fixed Effect Model (FEM) variabel yang termasuk rasio kesehatan keuangan dana tabarru' selain tingkat solvabilitas tidak berpengaruh signifikan terhadap profitabilitas perusahaan asuransi syariah karena ditunjukan dengan nilai probabilitas yang lebih besar dari 0,1.

Terdapat lima rasio kesehatan keuangan dana tabarru' selain tingkat solvabilitas rasio yang pertama adalah rasio likuiditas. Ketika likuiditas perusahaan menjadi meningkat maka perusahaan tersebut dikatakan dalam keadaan solven yang artinya perusahaan mempunyai dana cair yang bisa digunakan untuk membayar hutang dari klaim-klaim atau digunakan untuk membeli asset agar berinvestasi.

Kemampuan membayar bagi perusahaan asuransi dalam memenuhi kewajiban jangka pendek karena asuransi ketika ada klaim yang terjadi maka harus segera diproses dan perusahaan asuransi yang mempunyai dana likuid yang cari akan lebih aman karena sewaktu-waktu bisa digunakan untuk membayar kewajiban klaim nasabah. Selain itu, rasio likuiditas tidak berpengaruh secara langsung karena ini berhubungan dengan dana tabarru' yang harus segera memberikan dananya kepada peserta yang mengklaim sehingga dananya akan berkurang dan tidak akan menambah profit perusahaan.

Rasio perimbangan investasi dengan kewajiban tidak memiliki perngaruh yang signifikan terhadap profitabilitas keuangan dikarenakan ada rasio-rasio lainnya sebagai penguhubung untuk bisa mempengaruhi secara langsung profitabilitas perusahaan.

Rasio perimbangan investasi dengan kewajiban terdiri dari investasi, kas dan bank yang dibandingkan dengan beban penyisihan teknis dan hutang klaim retensi sendiri. Rasio ini memiliki asset yang digunakan untuk berinvestasi akan tetapi beban yang ditanggung dan hutang klaim masih belum terpenuhi sehingga akan mengurangi investasinya dan menurunkan pendapatan. 
Safitri, et al/Jurnal Ekonomi Syariah Teori dan Terapan Vol. 4 No. 1 Januari 2017: 73-88; ANALISIS RASIO KESEHATAN KEUANGAN DANA TABARRU' YANG MEMPENGARUHI PROFITABILITAS PADA ASURANSI SYARIAH DI INDONESIA (PERIODE 2012-2014)

Rasio pendapatan investasi neto adalah rasio yang digunakan untuk mengukur apakah investasi yang dilakukan sudah menguntungkan atau tidak sebab beberapa perusahaan asuransi tidak melakukan investasi ini, dana yang digunakan untuk investasi ini berasal dari dana tabarru' peserta asuransi. Sebagaian besar perusahaan mengandalkan hasil investasi untuk menutupi kekurangan akan tarif premi yang akan diberikan kepada tertanggung sehingga, investasi yang dilakukan bisa menghasilkan banyak return akan membantu jika ada klaim yang terjadi tetapi tidak bisa secara langsung berpengaruh terhadap profitabilitas perusahaan karena hasil investasi yang dilakukan harus digunakan untuk membayar atau dicadangkan ke dana tabarru'.

Rasio beban klaim adalah pengukuran dari beban klaim neto yang dibandingkan dengan pendapatan kontribusi neto, semakin tinggi pendapatan kontribusi neto semakin meningkat pula beban klaim yang akan terjadi artinya klaim yang akan semakin banyak disertai dengan pembayaran klaim yang meningkat dan hal itu akan menurunkan jumlah surplus underwriting sehingga dana yang dibagikan akan menjadi berkurang. Biaya klaim yang terus meningkat akan membawa dampak yang negatif terhadap profitabilitas karena jumlah beban yang dikeluarkan lebih besar daripada pemasukan, hal ini bisa menjadi bahan evaluasi untuk perusahaan.

Rasio perubahan dana tabarru' yang mempunyai hubungan positif tetapi tidak berpengaruh signifikan terhadap profitabilitas perusahaan asuransi syariah karena tidak serta merta berhubungan langsung terhadap profitabilitas karena berdampak pada surplus underwriting.

\section{Pengaruh Rasio Kesehatan Keuangan Dana Tabarru' Tingkat Solvabilitas Terhadap Profitabilitas}

Hipotesis keenam yaitu variabel bebas Risk Based Capital (RBC) berpengaruh signifikan positif terhadap profitabilitas perusahaan asuransi syariah terbukti. Risk Based Capital merupakan aturan yang mutlak dari pemerintah tiap asuransi konvensional dan syariah memiliki tingkat yang berbeda, perusahaan asuransi syariah yang diatur sesuai dengan PMK No 11/PMK/010/2011 harus menjaga tingkat solvabilitas dana tabarru' paling rendah sebesar $30 \%$ dari dana yang diperlukan untuk mengantisipasi risiko kerugian yang mungkin timbul sebagai akibat dari deviasi dalam pengelolaan kekayaan atau kewajiban.

Pentingnya ukuran RBC ini bagi perusahaan asuransi dapat dijadikan sebagai salah satu alat promosi perusahaan untuk membentuk brand image masyarakat bahwa perusahaan yang ditawarkan sehat dan bisa menjanjikan. RBC merupakan cara menuju pengembangan suatu system pengawasan keuangan perusahaan asuransi yang lebih sehat dengan berbasis 
Safitri, et al/Jurnal Ekonomi Syariah Teori dan Terapan Vol. 4 No. 1 Januari 2017: 73-88; ANALISIS RASIO KESEHATAN KEUANGAN DANA TABARRU' YANG MEMPENGARUHI PROFITABILITAS PADA ASURANSI SYARIAH DI INDONESIA (PERIODE 2012-2014)

risiko, idealnya perusahaan asuransi yang

Rasio kesehatan kevangan dikategorikan sehat juga berpengaruh pada perolehan profitnya. Penjelasan diatas menjadi suatu bukti bahwa risk based capital dapat berpengaruh terhadap profitabilitas perusahaan asuransi. Risk based capital dapat dijadikan sebagai pengambil keputusan bagi calon nasabah untuk mengasuransikan, pengambil keputusan bagi para investor untuk menanamkan modalnya untuk berinvestasi, menjadi focus utama OJK dalam melakukan pengawasan dan menjadi bahan evaluasi untuk perusahaan asuransi dalam meningkatkan usahanya.

Pengaruh Secara Simultan Rasio
Kesehatan Keuangan Dana Tabarru'
Terhadap Profitabilitas Perusahaan

\section{Asuransi Syariah di Indonesia}

Hasil output dari Eviews mennjukan bahwa uji $F$ secara simultan memiliki angka sebesar 0.00000 lebih kecil dari 0,1 yang artinya secara bersamaan variabel rasio likuiditas, rasio perimbangan investasi dengan kewajiban, rasio pendapatan investasi neto, rasio beban klaim, rasio perubahan dana tabarru', dan risk based capital berpengaruh terhadap profitabilitas yaitu $R O E$, hal ini juga didukung oleh $\mathrm{R}^{2}$ yang sebesar $87,59 \%$.

. Pengaruh secara simultan yang kuat terhadap profitabilitas sangatlah jelas karena masing-masing rasio tersebut merupakan gambaran dari hasil kinerja perusahaan asuransi dalam periode tertentu yang terdapat dipos yang berbeda-beda. 
Safitri, et al/Jurnal Ekonomi Syariah Teori dan Terapan Vol. 4 No. 1 Januari 2017: 73-88; ANALISIS RASIO KESEHATAN KEUANGAN DANA TABARRU' YANG MEMPENGARUHI PROFITABILITAS PADA ASURANSI SYARIAH DI INDONESIA (PERIODE 2012-2014)

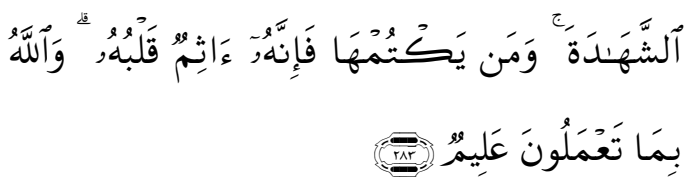

Wa in kuntum 'alā safariw wa lam tajidū kātiban fa rihānum maqbūdah, fa in amina ba'dukum ba'dan falyu 'addillazi' tumina amānatahū walyatta qillāha rabbah, wa lā taktumusysyahādah, wa may yaktum-hā fa innahū āsimun qalbuh, wallāhu bimā ta'malūna 'alim

Artinya : jika kamu dalam perjalanan (dan bermu'amalah tidak secara tunai) sedang kamu tidak memperoleh seorang penulis, Maka hendaklah ada barang tanggungan yang dipegang (oleh yang berpiutang). akan tetapi jika sebagian kamu mempercayai sebagian yang lain, Maka hendaklah yang dipercayai itu menunaikan amanatnya (hutangnya) dan hendaklah ia bertakwa kepada Allah Tuhannya; dan janganlah kamu (para saksi) Menyembunyikan persaksian. dan Barangsiapa yang menyembunyikannya, Maka Sesungguhnya ia adalah orang yang berdosa hatinya; dan Allah Maha mengetahui apa yang kamu kerjakan.

\section{SIMPULAN}

Berdasarkan hasil analisis dan pembahasan yang telah dilakukan maka dapat diambil kesimpulan sebagai berikut:

1. Rasio likuiditas tidak berpengaruh signifikan terhadap profitabilitas pada perusahaan asuransi syariah karena memiliki tingkat signifikansinya lebih besar dari 0.1 yaitu sebesar 0.8286

2. Rasio perimbangan investasi dengan kewajiban tidak berpengaruh signifikan terhadap profitabilitas pada perusahaan asuransi syariah karena memiliki tingkat signifikansinya lebih besar dari 0,1 yaitu sebesar 0.239
3. Rasio pendapatan investasi neto tidak berpengaruh signifikan terhadap profitabilitas pada perusahaan asuransi syariah karena tingkat signifikansinya lebih besar dari 0,1 yaitu sebesar 0.913

4. Rasio beban klaim tidak berpengaruh signifikan terhadap profitabilitas pada perusahaan asuransi syariah karena tingkat signifikansinya lebih besar dari 0,1 yaitu sebesar 0.9816

5. Rasio perubahan dana tabarru' tidak berpengaruh signifikan terhadap profitabilitas pada perusahaan asuransi syariah karena tingkat signifikansinya lebih besar dari 0,1 yaitu sebesar 0.3167

6. Rasio Risk Based Capital (RBC) memiliki pengaruh yang signifikan terhadap profitabilitas pada perusahaan asuransi syariah, karena tingkat signifikansinya lebih kecil dari 0,1 yaitu 0.0667

\section{Daftar Pustaka}

Ajija, Shochrul R., Dyah W. Sari, Rahmat H. Setianto, Martha R. Primanti. 2011. Cara Cerdas Menguasai Eviews. Jakarta: Salemba Empat.

Ali, Hasan. 2005. Asuransi Dalam Perspektif Hukum Islam. Jakarta: Kencana

Departemen Agama RI. 2012. Al-Qur'an Transliterasi Per Kata dan Terjemah Per Kata. Bekasi: Cipta Bagus Segara.

Dewan Syariah Nasional (DSN) Majelis Ulama Indoensia (MUI), Fatwa Dewan Syariah Nasional No: 21/DSNMUI/X/2001 tentang Pedoman Umum Asuransi Syariah, Jakarta; 2001.

Fitriani, 2015. Pengaruh Risk Based Capital Terhadap Profitabilitas pada Perusahaan Asuransi Syariah AXA Mandiri Periode 2011-2013. Skripsi tidak diterbitkan. Fakultas Ekonomi Universitas Islam Bandung. 
Gujarati, Damodar. 2013. Ekonometrika Dasar Buku 2. New York: The McGrawHill Companies, Inc.

Greene, William H. 1991. Econometric Analysis. New York: Macmillan Publishing Company.

Harahap, Sofyan Syafri. 2001. Analisis Kritis Laporan Keuangan. Jakarta: Bumi Aksara

lqbal, Muhaimin. 2005. Asuransi Umum Syariah dalam Praktik. Penerbit Gema Insani. Jakarta.

Peraturan Ketua BAPEPAM LK Nomor:PER06/BL/2012 Tentang Bentuk dan Susunan Laporan Serta Pengumuman Laporan Usaha Asuransi dan Usaha Reasuransi dengan Prinsip Syariah.

Pramestika, Dian. 2014. Pengaruh Tingkat Kesehatan Perusahaan Asuransi terhadap Pertumbuhan Premi Neto dan Profitabilitas. Skripsi tidak diterbitkan. Surabaya Fakultas Ekonomi dan Bisnis Universitas Airlangga.

Republik Indonesia. Peraturan Menteri Keuangan Nomor 11/PMK.010/2011 tentang Kesehatan Kevangan Usaha Asuransi dan Usaha Reasuransi dengan Prinsip Syariah

Satria, Salustra. 1994. Pengukuran Kinerja Keuangan Perusahaan Asuransi Kerugian di Indonesia dengan Analisis Rasio Kevangan "Early Warning System". Jakarta: Lembaga Penerbit FEUI 